\title{
Eficácia do princípio \\ da igualdade nas relações jurídicas privadas*
}

\section{Thiago Penido Martins ${ }^{* *}$}

Resumo: O cerne do problema a ser investigado está em definir a extensão da eficácia do princípio da igualdade nas relações jurídicas privadas contratuais, analisando em que medida os particulares, em suas relações jurídicas privadas contratuais, estão vinculados ao direito fundamental à igualdade. Podem os particulares, no exercício de sua autonomia privada e liberdade contratual, livremente elegerem o outro sujeito contratual e definir o conteúdo do contrato, inclusive para conferir tratamentos diferenciados ou estariam os particulares vinculados ao direito fundamental à igualdade, estando proibida toda e qualquer forma de discriminação no âmbito de suas relações jurídicas privadas? Existe uma margem de liberdade que assegura aos particulares, no exercício de sua autonomia privada, a possibilidade de promoverem tratamentos diferenciados? Podem os particulares se recusar em a celebrar negócios jurídicos com outros particulares em razão de critérios como raça, sexo, idade, orientação religiosa, orientação sexual, ou qualquer outro critério diferenciador? Esse é o instigante tema que se propõe analisar com o presente artigo.

* Fecha de recepción: 20 de diciembre de 20r6. Fecha de aceptación: 22 de mayo de 20i 7.Para citar el artículo: Martins, T. P., "Eficácia do princípio da igualdade nas relações jurídicas privadas", Revista de Derecho Privado, Universidad Externado de Colombia, n. ${ }^{\circ}{ }^{2}$, enero-junio de 2017, I09-I40. DOI: https://doi.org/Io. I860I/or 234366.n32.05

** Doutor em Direito Civil pela puc Minas; mestre em Direito de Empresa pela Faculdade Milton Campos; especialista em Direito Público pela Faculdade Milton Campos. Procurador autárquico municipal. Professor do Programa de Mestrado Stricto Sensu da Universidade de Itaúna - uit. Professor dos cursos de graduação e pós-graduação da PUC-MG, Faculdade Novos Horizontes. Contato: thiagopenido@yahoo.com.br 
Palavras-chave: direitos fundamentais, igualdade, autonomia privada, liberdade de contratação, livre desenvolvimento de personalidade.

\section{Eficacia del principio de igualdad en las relaciones jurídicas entre particulares}

Resumen: El artículo pretende definir la extensión de la eficacia del principio de la igualdad en el ámbito de las relaciones contractuales privadas, analizando en qué medida los particulares en sus relaciones están vinculados por el derecho fundamental a la igualdad. ¿Pueden los particulares, en el ejercicio de su autonomía privada y libertad contractual libremente elegir su contraparte y definir el contenido del contrato, inclusive para conferir tratamientos diferenciados? $\mathrm{O}$ ¿están los particulares vinculados al derecho fundamental a la igualdad, estando prohibida cualquier forma de discriminación en el ámbito de sus relaciones privadas? Existe un margen de libertad que asegura a los particulares, en el ejercicio de su autonomía privada, la posibilidad de promover tratamientos diferenciados? ¿Pueden los particulares rechazar la celebración de negocios jurídicos en razón de criterios como la raza, sexo, edad, orientación religiosa, orientación sexual, o cualquier otro criterio diferenciador?

Palabras clave: derechos fundamentales, igualdad, autonomía privada, libertad de contratación, libre desarrollo de personalidad.

Sumário: Introdução. I. Eficácia do princípio da igualdade nas relações privadas. II. Eficácia do princípio da igualdade nas relações jurídicas estritamente privadas. A. Igualdade e liberdade associativa. B. Igualdade nas relações familiares e sucessórias. C. Igualdade nas relações em que predominam aspectos relacionados à intimidade e privacidade, a religiosidade ou confiança. Considerações finais. Referências bibliográficas.

\section{Introdução}

Hodiernamente, uma das temáticas mais controversas e que tem despertado o interesse de inúmeros estudiosos é aquela relativa à eficácia dos direitos fundamentais no âmbito das relações jurídicas entre particulares, em especial, quando o objetivo é definir a extensão da eficácia dos direitos fundamentais nessas relações jurídicas. A questão da eficácia dos direitos fundamentais nas relações jurídicas entre particulares assume especial relevo, haja vista que seu estudo demandará, necessariamente, a análise das relações existentes entre as normas jurídicas constitucionais e as normas jurídicas de direito privado, bem como o conflito entre direitos fundamentais no âmbito de relações jurídicas privadas. 
$\mathrm{O}$ artigo tem o desiderato de proceder ao estudo da eficácia do princípio da igualdade no âmbito das relações jurídicas entre particulares, com o intuito de contribuir para o desenvolvimento dos debates existentes e aperfeiçoamento das construções teóricas que foram desenvolvidas ao longo das últimas décadas, na tentativa de formular proposições adequadas, capazes de conciliar a promoção do princípio da igualdade e sua correlata proibição de práticas discriminatórias, com a necessidade em se conferir segurança jurídica a estas relações jurídicas, mediante a proteção da autonomia privada e da liberdade contratual, corolários do direito fundamental ao livre desenvolvimento da personalidade.

O cerne do problema a ser investigado está em definir a extensão da eficácia do princípio da igualdade no âmbito das relações jurídicas privadas contratuais, analisando em que medida os particulares, no âmbito de suas relações jurídicas privadas contratuais estão vinculados ao direito fundamental à igualdade. Podem os particulares, no exercício de sua autonomia privada e liberdade contratual livremente elegerem o outro sujeito contratual e definir o conteúdo do contrato, inclusive para conferir tratamentos diferenciados ou estariam os particulares vinculados ao direito fundamental à igualdade, estando proibida toda e qualquer forma de discriminação no âmbito de suas relações jurídicas privadas? Existe uma margem de liberdade que assegura aos particulares, no exercício de sua autonomia privada, a possibilidade de promoverem tratamentos diferenciados? Podem os particulares se recusarem a celebrar negócios jurídicos com outros particulares em razão de critérios como raça, sexo, idade, orientação religiosa, orientação sexual, ou qualquer outro critério diferenciador?

A questão apresenta-se controversa e polêmica, uma vez que o reconhecimento da eficácia absoluta do princípio da igualdade no âmbito das relações jurídicas privadas, com o desiderato de coibir todo e qualquer tratamento diferenciado, poderia, para além de ocasionar demasiada restrição de sua autonomia privada, privá-los do direito de exercerem sua liberdade ou outros direitos fundamentais. Sustentar de forma acrítica a eficácia absoluta do princípio da igualdade nas relações jurídicas entre particulares poderia acarretar sérios prejuízos às relações jurídicas contratuais e ao direito de livre desenvolvimento da personalidade.

O trabalho tem como objetivo o estudo da relação existente entre liberdade e igualdade nas relações jurídicas entre particulares, identificando os limites que o princípio da igualdade impõe ao exercício da autonomia privada e da liberdade contratual, bem como a análise das situações em que o princípio de igualdade não possui eficácia ou possui uma eficácia muito restrita nas relações jurídicas entre particulares. Poderia o particular, se recusar a contratar ou estabelecer tratamento diferenciado motivado pelo sexo, raça, origem, religião, ou qualquer outro fator diferenciador do outro sujeito contratual? Poderia o locatário promover o despejo de um de seus locadores e não o fazer em relação a outro identicamente 
inadimplente? Poderia uma associação restringir a condição de associado à pessoa de determinada religião, sexo, raça, origem ou outro critério diferenciador?

Podem os pais conferirem tratamentos diferenciados aos seus filhos no âmbito das relações familiares ou sucessórias, privilegiando um filho em detrimento do outro, por exemplo, ao doar ou testar os bens? Podem os estabelecimentos empresariais que ofertam bens ou serviços ao público estabelecerem condições contratuais diferenciadas em razão da raça, sexo, idade, orientação religiosa, orientação sexual ou qualquer outro fator diferenciador? Podem os estabelecimentos abertos ao público estabelecerem condições diferenciadas de admissão ou recusá-la a determinadas pessoas em razão em razão da raça, sexo, idade, orientação religiosa, orientação sexual ou qualquer outro fator diferenciador? Essas são apenas algumas das conflituosas situações que se apresentam quando se trata de definir em que medida os particulares se encontram vinculados ao princípio da igualdade em suas relações jurídicas privadas.

\section{Eficácia do princípio da igualdade nas relações privadas}

Ao se analisar a eficácia do princípio da igualdade e da proibição de discriminação no âmbito das relações jurídicas entre particulares, indispensável distinguir duas distintas espécies de relações jurídicas, quais sejam, as relações jurídicas estritamente privadas, conformadas entre particulares em situação de relativa igualdade, nas quais a pessoa do contratante é relevante; e as relações jurídicas em que há a oferta e o fornecimento de bens e serviços ao público em geral, caracterizadas como relações de natureza consumerista, nas quais a pessoa do contratante é irrelevante ou pouco relevante, se aperfeiçoando com qualquer indivíduo que aceite as condições propostas pelo ofertante. ${ }^{\mathrm{I}}$ Estes contratos caracterizam-se como contratos de adesão ou contratos em massa, os quais podem ter como objeto bens ou serviços privados ou públicos, sendo que, neste caso, os particulares prestam serviços ou ofertam bens sob a forma de concessão ou permissão pelo poder público.

A distinção entre relações estritamente privadas e relações jurídicas em que há um interesse público tem sua origem do "direito antidiscriminatório" norte-americano, no qual há uma nítida separação entre a atuação privada para a promoção do acesso a bens e serviços de interesse público ou socialmente rele-

I McCrorie sustenta a importância em distinguir a esfera estritamente privada do agir humano, daquela esfera em que seu agir tenha uma relação permanente com o público. Conforme destaca: "Parece-nos que deverá utilizar também, como critério de distinção, o facto das actividades se enquadrarem na esfera privada ou na esfera pública do particular, sendo que entendemos abrangidas nesta última aquelas em que este se encontra numa relação permanente com o público. Assim, tratando-se de actividades que se enquadrem na esfera privada, parecenos que dificilmente haverá razões sociais suficientemente poderosas que possa justificar uma restrição da autonomia individual e, consequentemente, a imposição de um dever de igualdade aos indivíduos" (McCrorie, 2005, 48). 
vantes e a atuação privada voltada para a promoção de atividades propriamente privadas, desprovidas de qualquer interesse público. ${ }^{2}$ A distinção se apresenta relevante uma vez que, a depender da natureza jurídica da relação jurídica entre particulares, o grau de eficácia do princípio da igualdade e a correlata proibição de discriminação será completamente distinto. ${ }^{3}$

\section{Eficácia do princípio da igualdade nas relações jurídicas estritamente privadas}

Nas relações jurídicas estritamente privadas, celebradas entre particulares em situação de relativa igualdade, o princípio da igualdade terá reduzida ou nenhuma eficácia. É o que acontece, por exemplo, nas relações jurídicas de locação de bens imóveis, nas relações jurídicas em que a proteção da privacidade, intimidade ou vida privada do contratante é indispensável, nas relações jurídicas decorrentes do exercício da liberdade associativa, nas relações jurídicas em que a confiança ou proximidade constituem traços característicos, nas relações jurídicas familiares e sucessórias, nas relações em que o exercício da autonomia privada está diretamente relacionado às convicções religiosas do contratante,bem como nas relações em que a vontade de contratar se dirige a pessoas determinadas.

Nestas relações jurídicas há que se assegurar ao contratante alguma margem de discricionariedade para exercer ou não sua liberdade de contratação, eleger o outro sujeito contratual, definir a forma e o conteúdo do contrato, de modo a tutelar sua autonomia privada e garantir-lhe a possibilidade de livremente desenvolver sua personalidade de acordo com seus interesses e necessidades. O princípio da igualdade e sua correlata proibição de discriminação teriam o condão de limitar a autonomia privada e a liberdade de contratação ao ponto de impor o dever de contratar aos particulares, ao proibir que o contratante eleja o outro sujeito contratual baseando-se em suas características pessoais, tais como idade, sexo, orientação sexual, raça, ou qualquer outra similar? A proibição de discriminação tornaria ilícito qualquer tratamento diferenciado realizado no âmbito de uma relação jurídica contratual? Caso permitido o tratamento dife-

2 Aguilera Rull, 2009, i 8. Em igual sentido Bilbao Ubillos: "En este sentido podría resultar útil la solución adoptada por el ordenamento norteamericano, que siempre ha distinguido dos esferas dentro del sector privado: una relacionada con el acceso a bienes y servicios de interes público, socialmente relevantes, y otra que comprende las actividades propiamente privadas, carentes de esa proyección pública" (BILBAO UBillos, 2006, 824).

3 Conforme argumenta McCrorie: "Parece que podemos, então, distinguir as seguintes situações: quando o particular actua na sua esfera privada, não surgindo abertamente no mercado, entendemos que ele não se deverá encontrar vinculado ao princípio da igualdade. Nesse âmbito, parece fazer sentido considerar que, em princípio, as diferenças de tratamento que tem a sua origem em decisões tomadas por sujeitos privados em igualdade de circunstâncias não são ilícitas em si mesmas. Só se qualificarão como tais aquelas que impliquem, além disso, a violação de outros valores constitucionais substantivos" (MCCrorie, 2005, 47). 
renciado, estará o particular obrigado a justificá-lo? Conforme destaca Bercovitz Rodríguez-Cano:

A eficácia do princípio da igualdade dentro do âmbito jurídico privado é muito menor que frente aos poderes públicos. É inerente ao próprio conceito de autonomia privada o predomínio da vontade individual sobre a igualdade: se contrata com quem se quer e como se quer, se dispõe em testamento a favor de quem se quer e como se quer, se doa a quem se quer e como se quer, se associa se com quem quer e para o que quiser, se constitui uma fundação para o que um quer com a dotação que se quiser, se exercem direitos face a quem se quiser, naturalmente todos eles dentro dos limites marcados pelas normas imperativas (Bercovitz Rodríguez-Cano, I990, 424, tradução nossa).4

As relações jurídicas estritamente privadas constituem espaço de liberdade, intimidade e de certa discricionariedade para que as pessoas possam livremente desenvolver suas relações humanas, sejam afetivas, sexuais, familiares ou de fraternidade, espaços em que há uma maior liberdade para que os particulares possam adotar decisões de forma autônoma, de modo que, impor-lhes a obrigatoriedade de sempre observar o princípio da igualdade e uma rígida proibição de discriminação, afetaria severa e profundamente a liberdade de decisão e de desenvolvimento dessas relações humanas. Seria inadequado estender a eficácia do princípio da igualdade a essas relações humanas, de modo a proibir que alguém livremente escolha seu cônjuge, as pessoas com deseja se relacionar de forma intimista, devendo se assegurar, a mais absoluta liberdade para eleger com quem contratar, por mais curiosos, diferentes ou moralmente repudiantes que sejam os motivos adotados para a eleição, seja raça, aparência, estrato social, orientação sexual, dentre outros. Destaca Díaz de Valdés:

4 Conforme texto original: "La eficácia do princípio da igualdad dentro de este ámbito jurídico-privado es mucho menor que frente a los poderes públicos. Es inherente al propio concepto de autonomia privada el predomino de la voluntad individual sobre la igualdad: se contrata com quien se quiera y como se quiera, se dispone en testamento a favor de quien uno quiere y como si quiera, se dona a quien se quiera e como se queira, se associa uno com quien quiera y para lo que quiera, se constituye una fundación para lo que uno quiera y con la dotación que se quiera, se ejercen derechos frente a quien uno quiera, naturalmente todo ello dentro de los limites marcados por las normas imperativas". Em igual sentido destaca Verda y Beamonte: "en los negocios gratuitos el derecho fundamental a la no discriminación tendrá un escaso margen de incidencia, de modo que podrá donar bienes a quien quiera y como quiera; y lo propio cabe decir de las disposiciones testamentarias; el testador, respecto de la parte de sus bienes de libre disposición, podrá favorecer a una persona y excluir a otra, por motivos de fe religiosa, convicciones politicas, raza u otros. En opinión de este autor, esta prevalecia del valor superior de la libertad sobre la igualdad tendrá lugar incluso cuando se trate de negocio jurídico fundacional. La incidencia del derecho fundamental a la no discriminación será, en cambio, mayor en los contratos onerosos, sobre todo cuando se trate de contratos que racaigan sobre materias socialmente importantes y cuando el sujeto discriminador tenga una posición total o parcialmente dominante en el mercado o en la sociedad" (Verda y Beamonte, 200 I, 65). 
O respeito e proteção à vida privada assegura, entre outras coisas, um espaço de intimidade às pessoas para que possam desenvolver as relações humanas mais fundamentais (efetivas, românticas, sexuais, familiares e de amizade), assim como adotar com a maior liberdade possível suas decisões autônomas. Uma proibição de discriminação entre particulares, sem embargo, afetaria severamente essa liberdade de decisão, assim como o desenvolvimento das relações humanas mencionadas. E mais, uma proibição absoluta resulta impensável, já que destruiria por completo o direito em questão. Basta para imaginar que não se pudesse discriminar na eleição do cônjuge: toda pessoa requer a mais absoluta liberdade nesta matéria, por mais curiosos ou repudiáveis que nos pareçam seus motivos para eleger (raça, aparência, estrato social, riqueza, etc.) (Díaz De Valdés, 20 I4, I6 I, tradução nossa). 5

Sob essa perspectiva é plenamente lícito que uma pessoa não queira se casar com pessoas de determinada religião, raça ou origem étnica, que não queria manter laços de proximidade ou amizade com pessoas de determinada orientação sexual, que manifeste seu desejo de apenas de se relacionar com pessoas de determinado estrato social, desde que não lhes confira tratamentos vexatórios, degradantes ou humilhantes. Os referidos comportamentos podem até ser moralmente ou socialmente questionados e refutados, todavia não configuram discriminações ilícitas ao ponto do destinatário do tratamento diferenciado poder exigir que lhes sejam conferidos tratamentos iguais aos dispensados a outros indivíduos. ${ }^{6} \mathrm{O}$ que não se admite é que as escolhas pessoais e projetos de vida sejam exercidos em detrimento da dignidade dos demais indivíduos, afetando a humanidade que é inerente a todo indivíduo, tão somente em razão de suas características pessoais, diminuindo-o enquanto pessoa.

Exigir que particulares, no exercício da autonomia privada e liberdade de contratação, dispensem aos demais idêntico tratamento ou que justifiquem os

5 Conforme texto original: "El respeto y protección a la vida privada asegura, entre otras cosas, un espacio de intimidad a las personas para que puedan desarrollar las relaciones bumanas más fundamentales (e.g., afectivas, románticas, sexuales, familiares, de amistad), así como adoptar con la mayor libertad posible sus decisiones autónomas. Una probibición de discriminación entre particulares, sin embargo, afectaría severamente esta libertad de decisión, así como el desarrollo de las relaciones humanas mencionadas. Es más, una probibición absoluta resulta impensable, ya que destruiría por completo el derecho en cuestión. Baste para ello imaginar que no se pudiese discriminar en la elección del cónyuge: toda persona requiere la más absoluta libertad en esta materia, por curiosos o repudiables que nos parezcan sus motivos para elegir (e.g., raza, apariencia, estrato social, riqueza, etc.)".

6 Esse também é o entendimento de Sarmento, para quem: "de forma alguma poder-se-ia obrigar juridicamente alguém, com base na vinculação dos particulares aos direitos fundamentais, a tornar-se amigo de uma pessoa de outra cor ou religião, ou a convidá-la para sua festa de aniversário, ainda que se pudesse, no plano extrajurídico, criticar a intolerância e o racismo de seu comportamento. É porque nestes últimos casos, estamos lidando com decisões de caráter existencial, que se revestem de um colorido emocional e estão protegidas pelo direito à privacidade" (SARMENTo, 2006, 268). 
tratamentos diferenciados realizados configuraria uma restrição demasiada e indevida, representaria, segundo a visão de Neuner, impor-lhes um dever positivo de sempre conferir tratamento igualitário aos demais sujeitos privados.7 Sob a perspectiva da tutela do direito de livremente desenvolver sua personalidade, deve ser assegurado aos indivíduos a possibilidade de construir seus projetos de vida de acordo com seus sentimentos, inclinações pessoais, concepções de mundo. ${ }^{8}$ Poderia o particular, se recusar a contratar ou estabelecer condições contratuais diversas em razão do sexo, raça, origem, religião, ou qualquer outro fator diferenciador do outro sujeito contratual, ou estaria, em nome do princípio da igualdade e proibição de discriminação obrigado a contratar em todas essas situações?9 Conforme destaca Steinmetz:

O espaço de liberdade do particular é maior do que o do legislador. Ao particular está permitido o tratamento com base em escolhas casuais, preferências de foro íntimo, sentimentos de simpatia e inclinações em geral; ao legislador, não. Este sempre deverá deferir tratamento igual ou tratamento diferenciado apoiado em razões objetiva e intersubjetivamente controláveis (Steinmetz, 2004, 258).

A análise da licitude da recusa em se contratar ou do tratamento diferenciado nas relações jurídicas entre particulares, em inúmeros casos, não se limitará à eficácia do princípio da igualdade face à autonomia privada e à liberdade de contratação. Em diversas situações jurídicas concretas, esse conflito entre direitos fundamentais será incrementado pela incidência de outros direitos fundamentais, muitos deles desdobramentos da autonomia privada, tal como ocorre quando a recusa em se contratar em razão do sexo esteja relacionada à necessidade de proteção da intimidade ou privacidade do contratante ou de terceiros, como por exemplo, a restrição de acesso a saunas, clubes, academias ou mesmo salões de beleza destinados a um público específico, bem como nos casos em que a recusa em se contratar decorra da necessidade de se tutelar a liberdade de crença e religião

7 Neuner, 2007, $5^{8}$.

8 Em igual sentido, Sarmento destaca: "Existem situações que o preço a ser pago pela submissão dos particulares aos direitos fundamentais torna-se caro demais. Ela, em certos termos, pode levar à asfixia da espontaneidade das relações humanas, à homogeneização forçada com comportamento individual a partir de pautas tidas como politicamente corretas, às custas do pluralismo e da própria dimensão libertadora que caracteriza os direitos fundamentais" (SARMENTO, 2006, 268-269).

9 Vieira de Andrade questiona: "se o senhorio pode despejar um inquilino por não pagamento da renda quando tolera a permanência de outro que também não paga; se uma pessoa pode legitimamente deixar os seus bens por testamento apenas a familiares de um dos sexos, excluindo intencionalmente os do outro; se os donos de hotéis, táxis e restaurantes, bem como escolas ou de clubes privados, podem recusar a permanência, o transporte, o serviço ou a frequência de certas categorias de pessoas (estrangeiros, pessoas de raça diferente ou de determinado sexo)" (Vieira de Andrade, 2009, 235-236). 
dos demais contratantes, como por exemplo, quando se estiver diante de uma associação de natureza religiosa.

A questão da eficácia do princípio da igualdade nas relações jurídicas entre particulares nem sempre se resumirá ao conflito entre autonomia privada, liberdade de contratação e igualdade. ${ }^{\text {Io }}$ Destaca Díaz de Valdés que, “a proibição de discriminação entre particulares pode violar outros bens valorados e protegidos pelo ordenamento jurídico constitucional” uma vez que a admissão da eficácia do princípio da igualdade nas relações jurídicas entre particulares, "implicaria em aceitar uma dose importante de intervenção estatal na vida das pessoas ou grupos, questão que pode afetar a vida privada, a liberdade de associação, a liberdade religiosa, a liberdade de expressão." I I Não é por outro motivo que estudiosos da eficácia do princípio da igualdade nas relações jurídicas privadas destacam a sua inaplicabilidade às relações estritamente privadas, especialmente quando o tratamento diferenciado também esteja assentado no exercício de outros direitos fundamentais assegurados pelo ordenamento jurídico. Conforme destaca Montoya Melgar:

... há que entender que no âmbito da contratação estritamente privadas as partes são absolutamente livres para decidir com quem contratar ou não, ou para estabelecer quantas medidas restritivas ou discriminatórias estime oportunas. A liberdade contratual se reduz dando espaço ao cumprimento do dever de igualdade nos contratos com projeção social (geralmente contratos com consumidores), quando existe um elemento público (utilização de espaço público ou recursos públicos) ou nos casos de monopólio (ou posição de domínio) (Montoya Melgar, 2007, 464, tradução nossa). ${ }^{\text {I2 }}$

Io Conforme destaca Díaz de Valdés, "existe la posibilidad de probibir la discriminación entre particulares sobre la base de otros derechos involucrados. En efecto, es común que los actos discriminatorios también afecten el ejercicio de un derecho diferente a la igualdad. Así, por ejemplo, si un alumno Sikh es expulsado de un colegio por usar su tradicional turbante, aquel puede alegar una vulneración a su libertad religiosa" (Díaz de VAldés, 2OI4, 5).

i I Díaz de Valdés, 20I4, 6. Conforme salienta o autor: "En otras palabras, la probibición de discriminación entre particulares puede vulnerar otros bienes valorados y protegidos por el ordenamiento constitucional. En efecto, aquella implicaría aceptar una dosis importante de intervención estatal en la vida de las personas y grupos, cuestión que puede afectar el derecho a la vida privada, la libertad de asociación, la libertad religiosa, la libertad de expresión, la autonomía de los cuerpos intermedios, la autonomía contractual, entre otros" (Díaz de VALdÉs, 2014, I6I).

I 2 Confome original, "bay que entender que en el ámbito de la contratación estrictamente privada las partes son absolutamente libres para decidir con quién contratan o no, o para establecer cuantas medidas restrictivas o discriminatorias estimen oportunas. La libertad contractual se reduce dando cabida al cumplimiento del deber de igualdad en los contratos con proyección social (generalmente, contratos con consumidores), cuando existe un elemento público (utilización de espacio público o fondos públicos) o en los casos de monopolio (o posición de dominio)". 
Não seria exigível que um particular deixe de exercer sua liberdade de crença e religião, sua privacidade ou intimidade para privilegiar o princípio da igualdade em uma relação jurídica estritamente privada, comprometendo seu direito de livremente desenvolver sua personalidade. Ademais, a eficácia do princípio da igualdade nas relações jurídicas entre particulares possui restrições que lhes são impostas pela estrutura e principiologia inerentes ao direito privado, em especial, pela necessidade de se tutelar a autonomia privada e a liberdade de contratação. Montoya Melgar salienta a importância de não se sacrificar em demasia a autonomia privada e liberdade de contratação:

... não pode sacrificar a todo custo o princípio da liberdade contratual, que compreende a liberdade de contratar ou não, de eleger o contratante e de determinar o conteúdo do contrato. A aplicabilidade do princípio da igualdade deve ser matizada, atenuada pela lógica interna do direito privado. Há que entender-se portanto que em virtude do princípio da autonomia da vontade as partes implicadas são livres para gerir seus próprios interesses e regular suas relações, sem imposições externas, salvo nos seguintes casos: quando exista uma posição monopolística ou dominante de uma entidade; nos casos de contratação em massa ou contratos de repercussão social e, nos casos em que se possa produzir uma afetação ao núcleo essencial da dignidade ou integridade moral da pessoa discriminada. Ademais, como resta obvio, o princípio da igualdade se impõe sempre que exista um componente público: prestação de serviços de interesse público. (Montoya Melgar, 2007, 474-475, tradução nossa). ${ }^{13}$

Díaz de Valdés também destaca que os particulares que forneçam bens e prestem serviços de natureza pública, na condição de concessionários ou permissionários, estão vinculados ao princípio da igualdade. Nestas hipóteses, a proibição de discriminação decorre do fato do particular fornecer bens ou prestar os serviços em substituição ao poder público, sendo notória a utilidade pública do bem ou serviço disponibilizado, razão pela qual são vedados os tratamentos diferenciados. De igual modo, aqueles que detenham o monopólio na oferta de bens ou prestação de serviços não poderão conferir tratamentos diferenciados nem recusarse a contratar, uma vez que sua recusa importará em obstáculo a que o indivíduo

I3 Conforme original: "Así pues, no puede sacrificarse a toda costo el principio de libertad contractual, que comprende la libertad de contratar o no, la de elegir el contratante y la de determinar el contenido del contrato. La aplicabilidad del principio de igualdad debe ser matizada, atenuada por la lógica interna del derecho privado. Ha de entenderse por tanto que en virtud del principio de autonomía de la voluntad las partes implicadas son libres para gestionar sus propios intereses y regular sus relaciones, sin imposiciones externas salvo en los siguientes supuestos: cuando exista una posición monopolística o dominante de una entidad; en los supuestos de contratación en masa o contratos de repercusión social y, en los casos en que pueda producirse una afectación al núcleo esencial de la dignidad o integridad moral de la persona discriminada. Además, y como resulta obvio, el principio de igualdad se impone siempre que exista un componente público: prestación de servicios de interes público". 
tenha acesso a determinado bem ou serviço, principalmente se se tratar de bem ou serviço essencial à pessoa.

Não se olvide também das intrínsecas e umbilicais relações existentes entre o princípio da igualdade, proibição de discriminação e dignidade da pessoa humana, de modo que a análise da licitude do tratamento diferenciado deverá identificar se ele proporciona tratamento vexatório, humilhante ou degradante, ao ponto de configurar lesão à dignidade daquele a quem foi dispensado. Nesse sentido é que a recusa em se admitir o ingresso de pessoas em locais abertos ao público tende a ser inadmitida, uma vez que, em regra, expõe aquele que não foi admitido a tratamento público vexatório. Alfaro Águila-Real destaca que quando há oferta realizada ao público, o ofertante acaba por renunciar ao direito de selecionar os contratantes sob bases individuais, de modo que a recusa, nessas circunstâncias, evidência uma discriminação ou desprezo pela pessoa inadmitida:

O caso mais patente é o de acesso a locais públicos, por quanto a abertura de um estabelecimento ao público implica em uma renúncia expressa a selecionar a clientela sob bases individuais, ainda quando caiba afirmar que haja a obrigação de contratar pelo mero fato da abertura. O que torna vexatória a negativa é que todo mundo sabe que em princípio se aceita contratar com qualquer um, razão pela qual a negativa não justificada só pode ser interpretada como um ato de desprezo e desvalorização, justamente a finalidade perseguida pelo discriminador (Alfaro Águila-Real, I 993, I I 9).

Díaz de Valdés, ao dissertar sobre a eficácia do princípio da igualdade e do postulado da proibição de discriminação nas relações jurídicas entre particulares, estabelece alguns tratamentos diferenciados que tendem a ser proibidos. De acordo com o autor, devem ser proibidos os tratamentos diferenciados que afetem de forma relevante a dignidade da pessoa ou que causem sua estigmatização ou da categoria a que ela pertença. Tendem também a ser ilícitos os tratamentos diferenciados que estejam baseados em características imodificáveis, historicamente utilizadas para reduzir a condição das pessoas, tais como a raça e a origem étnica. Nestes casos, somente em hipóteses excepcionais, desde que haja justificativa racional e legítima, o critério poderia ser adotado. $\mathrm{O}$ autor também sustenta a necessidade de se analisar os motivos ou causas que justificam o tratamento diferenciado. Nessa perspectiva, devem ser rechaçados os tratamentos diferenciados alicerçados em estereótipos ou convenções sociais, construídos irracionalmente em prejuízo de determinada categoria de pessoas, que dão azo a discriminações caprichosas ou não racionalmente justificáveis. ${ }^{\mathrm{I}}$

Por outro lado, será considerado lícito o tratamento diferenciado quando este for indispensável para proteger o núcleo, a essência de outro direito ou 
bem constitucional, tais como a liberdade de associação, liberdade de crença e religião, intimidade, privacidade e a própria liberdade de contratação, enquanto importantes expressões da autonomia privada. ${ }^{15}$ Nestes casos a licitude do tratamento diferenciado decorre da essencialidade desses direitos fundamentais interrelacionados, o que torna mais intensa a necessidade de se proteger a autonomia privada face ao princípio da igualdade e da proibição de discriminação, até mesmo como forma de se assegurar ao particular que possa livremente fazer escolhas, tomar decisões e desenvolver aspectos existências de seu projeto de vida. Nos casos em que a autonomia privada estiver alicerçada apenas ou preponderantemente em aspectos de natureza patrimonial ou econômica, a proteção da autonomia privada se dará de forma menos intensa face ao princípio da igualdade e sua correspondente proibição de discriminação.

Sarmento destaca a necessidade de que seja considerado o caráter existencial ou patrimonial das escolhas individuais, sem se olvidar que o comportamento humano pode envolver simultaneamente aspectos patrimoniais e existenciais, ao assim prelecionar:

De fato, existem certas ações humanas que envolvem apenas escolhas de caráter existencial, e neste campo a liberdade de agir deve ser protegida mais intensamente pela ordem jurídica. Outros comportamentos referem-se exclusivamente a questões patrimoniais e econômicas, e nestes casos a tutela constitucional à autonomia privada não deve se fazer tão forte. Mas, entre extremos, há um continuиm de situações em que o comportamento humano envolve, simultaneamente, aspectos patrimoniais e existenciais, em maior ou menor grau. Nestes casos, o nível de proteção constitucional conferido à ação do agente vai depender da posição dentro daquela escala: quanto mais o comportamento se aproximar da esfera das opções e valorações exclusivamente existenciais, maior será o nível de defesa constitucional da autonomia privada; quanto mais ele se afastar deste campo e se aproximar do universo exclusivamente econômico-patrimonial, menor será a tutela (Sarmento, 2006, I80).

Não se deve admitir tratamentos diferenciados caprichosos, desprovidos de qualquer justificativa, que tenham por objetivo tão somente discriminar a pessoa, de modo a reduzi-la, colocá-la em situação vexatória, degradante ou humilhante. Isso não significa que o particular tenha que justificar todas suas escolhas ou comportamentos, porque a liberdade do agir humano também é tutelada pelo ordenamento jurídico. Não devem ser toleradas escolhas ou comportamentos

I 5 Esse é também o entendimento de Díaz de Valdés, para quem: "Es decir, la discriminación entre privados sería tolerable sólo cuando ello sea necesario para proteger el 'corazón' de otro derecho (e.g., la privacidad exigiría total libertad para discriminar en la elección del cónyuge, pero no del chofer o la secretaria)" (DÍAZ DE VALDÉs, 2O I4, I 75). 
dissociados do exercício legítimo de direitos fundamentais. Tendem a ser igualmente considerados lícitos os tratamentos diferenciados, desde que não baseados na raça ou origem étnica, praticados de forma ocasional e esporádica desde que não possuam repercussão ou transcendência social. ${ }^{16}$

A eficácia do princípio da igualdade e da correlata proibição de discriminação face à autonomia privada dependerá, portanto, das especificidades da relação jurídica privada, dos direitos fundamentais em conflito, dos bens constitucionais cujo tratamento diferenciado se restringiu, se existenciais ou patrimoniais, das circunstâncias, do grau de simetria entre as partes, da autenticidade da vontade externada pelos contratantes, da transcendência ou repercussão social da diferenciação, e da análise da possível afetação da dignidade da pessoa discriminada.

Esses representam alguns dos principais critérios sugeridos para se definir o grau de eficácia do princípio da igualdade nas relações jurídicas entre particulares, os quais deverão ser considerados quando da análise do caso concreto para definir se haverá a necessidade de uma maior ou menor eficácia do princípio da igualdade face à autonomia privada e liberdade contratual. Os critérios tem o objetivo de balizar e estabelecer diretrizes interpretativas de modo a reduzir o subjetivismo das decisões jurisdicionais, evitando o esvaziamento do conteúdo da autonomia privada decorrente do intervencionismo jurisdicional nas relações jurídicas contratuais entre particulares.

Além dos critérios sugeridos, cumpre salientar que em determinadas relações jurídicas privadas, em razão de suas especificidades, a eficácia do princípio da igualdade será reduzida, como ocorre, por exemplo, nas relações de natureza associativa, familiares, sucessórias, bem com naquelas em que predominam aspectos relacionados à intimidade, a privacidade, confiança, crença religiosa. Nessas relações jurídicas, além da necessidade em se tutelar a autonomia privada e liberdade contratual, há a necessidade de se proteger o núcleo de outros direitos fundamentais que entram diretamente em conflito com o princípio da igualdade, tais como o direito a intimidade, privacidade, liberdade de crença e religião, razão pela qual serão objeto de estudo específico no próximo tópico.

\section{A. Igualdade e liberdade associativa}

Sob a perspectiva da liberdade associativa a análise da eficácia do princípio da igualdade e da proibição de discriminação assume outros contornos e explicitações. As associações privadas além de não configurarem estabelecimentos abertos ao público, não estão obrigadas, a princípio, a admitirem associados com base no princípio da igualdade, pois constituem espaços privados que permitem aos

i6 Díaz de VAldés, 20 14, 6-7. Em igual sentido, Bilbao Ubillos destaca: "bay que combatir, por tanto, la discriminación social, los usos o conductas discriminatorias privadas que tengan proyección social y resulten, por ello, intolerables" (Bilbao Ubillos, 2006, 822). 
seus associados desenvolverem seus interesses pessoais. As associações privadas são livres para elegerem aqueles com quem pretendam contratar e se associar, inclusive adotando como critério de eleição o sexo, a raça, a etnia, as crenças, as concepções religiosas, a comunhão ou identidade de interesses, sem que tais exigências possam ser consideradas ilícitas, uma vez que não representam qualquer afronta à dignidade daqueles que não foram aceitos como associados.

Nestas situações, além de se discutir o conflito entre a autonomia privada e o princípio da igualdade, se está diante de situações jurídicas em que se faz necessário discutir a eficácia do direito de liberdade de associação, por sinal, direito fundamental relacionado à autonomia privada. Assim, por exemplo, com base na liberdade de associação, é possível a existência de associações em que só mulheres, homens, brancos ou negros, possam se associar, das quais somente cristãos ou judeus possam participar, nas quais se exija que a pessoa possua os mesmos interesses dos demais associados? ${ }^{17}$

O direto de liberdade de associação, cujo fundamento decorre da tutela da autonomia privada, assegura aos indivíduos o direito de criar associações, associar-se ou não, permanecer associado segundo sua vontade, bem como de livremente eleger as pessoas com que deseja se associar. A decisão de pertencer ou não a determinada associação pode ser motivada pelos mais diversos fundamentos de índole pessoal, tais como identidade de ideologia ou de objetivos, comunhão de pensamentos entre os associados, de modo que, sustentar a eficácia do princípio da igualdade no âmbito das relações jurídicas associativas, proibindo-se qualquer espécie de discriminação, representaria séria e profunda violação ao direito de liberdade de associação, inclusive ao exigir que pessoas que não possuam identidade de ideologia ou de objetivos sejam compelidas a permanecerem associadas contra sua vontade.

Partindo do pressuposto de que a liberdade de associação assegura aos indivíduos a liberdade de eleger as finalidades a serem perseguidas pela associação, também se afigura natural e permitido que se estabeleçam condições de associação compatíveis com elas, de modo que seria lícito a uma associação composta por mulheres impedir a associação de homens, uma associação que tenha

I 7 Tem-se a notícia que determinado clube de golfe localizado no Estado do Rio de Janeiro estabelece limitações para o número de associados de origem japonesa. Em outro caso, os pretendentes a se associarem estão sujeitos a anuência dos demais associados em votação secreta. Para que o pretendente tenha a sua associação negada, basta que apenas um dos associados vote contra. A mesma lógica adotada para as associações é aplicada aos clubes privados, não abertos ao público em geral. Em determinado clube da capital mineira os empregados domésticos que acompanham os associados são impedidos de usufruírem das piscinas e saunas. Seria esse tratamento diferenciado legítimo? Poderia o clube privado exigir que os empregados domésticos utilizem vestimentas especiais indicando sua condição de acompanhante? De fato, a restrição à utilização dos serviços de piscina, saunas e demais atrativos do clube não parece constituir prática ilícita, uma vez que a pessoa não detém a qualidade de associado. Todavia, deve se ter cautela quanto aos procedimentos utilizados para diferenciar acompanhantes e associados, sendo vedada a utilização de qualquer procedimento ou mecanismo que lhes proporcione vexação ou humilhação. 
a finalidade de honrar a memória do holocausto se recuse a admitir aqueles que neguem sua existência, uma associação de apreciadores de vinhos ou charutos se recuse a admitir pessoas que não apreciem ou façam uso de tais mercadorias. ${ }^{18}$ Díaz de Valdés, ao analisar a eficácia do princípio da igualdade e da proibição de discriminação no âmbito das relações jurídicas de natureza associativa, alerta:

Em relação ao direito de associação, cabe recordar que este permite não somente filiar-se ou desfiliar-se, mas também a livre eleição com quem filiar-se. Com efeito, a decisão de pertencer a um grupo está muitas vezes condicionada, nos fatos, nas pessoas concretas que o integram (seja porque se busque uma maior camaradagem, um ambiente desafiante, uma companhia estimulante, capacidade sobressalente, etc.). Em consequência, proibir discriminar no acesso às associações pode traduzir-se em uma grave vulneração ao direito em comento, obrigando a manterem-se juntas pessoas que não desejam. Outra perspectiva a considerar é que a liberdade de associação supõe a livre eleição de seus fins por parte de seus membros (ou como determine os estatutos), questão que pode implicar em imposição de condicionantes para o ingresso (Díaz de Valdés, 20I4, I62, tradução nossa). ${ }^{19}$

O exercício do direito de admissão de pretensos associados estará vinculado à observância dos fins associativos e a vontade dos associados, de modo que se apresenta inadmissível impor-lhes um dever de admitir pessoas que possam comprometer a vontade dos membros associados ou a realização dos fins associativos por eles objetivados e perseguidos. ${ }^{20}$ Em outras situações, a tutela da

I8 O texto constitucional é expresso, no inciso xvII, de seu artigo $5^{\circ}$, ao preceituar que a liberdade de associação somente poderá ser exercida para fins lícitos, de modo que uma associação que tenha por objetivo discriminar e lesionar os direitos de determinada categoria de pessoas em razão de sua raça, origem étnica, orientação sexual, sexo, idade, ou qualquer outro fator, será considerada ilícita.

I9 Conforme texto original: "En relación al derecho de asociación, cabe recordar que este permite no sólo afiliarse o desafiliarse, sino también la libre elección de con quién afiliarse. En efecto, la decisión de pertenecer o no a un grupo está muchas veces condicionada, en los bechos, a las personas concretas que lo integran (ya sea porque se busque una mayor camaradería, un ambiente desafiante, una compañía estimulante, capacidad sobresaliente, etc.). En consecuencia, probibir discriminar en el acceso a las asociaciones puede traducirse en una grave vulneración al derecho en comento, obligando a mantenerse juntas a personas que no lo desean. Otra perspectiva a considerar es que la libertad de asociación supone la libre elección de sus fines por parte de sus miembros (o como se determine en los estatutos), cuestión que puede implicar la imposición de condicionantes para el ingreso a la misma".

20 Conforme destaca Díaz de Valdés: "Tal autonomía supone la facultad de autogobernarse mediante autoridades y normas propias, las que incluyen el establecimiento de reglas de admisión. El ámbito y contenido de la autonomía garantizada, sin embargo, se vincula a los fines de la asociación, determinados por su naturaleza (elemento objetivo) y la voluntad de sus miembros (elemento subjetivo). Por lo tanto, la probibición de discriminación vulneraría la autonomía garantizada constitucionalmente de estos cuerpos si de alguna forma repercute en el cumplimiento de sus fines" (DíAz DE VALDÉs, 20I4, I62) 
liberdade de associação estará diretamente relacionada à garantia da liberdade de expressão.

No direito norte-americano, a Suprema Corte, tem se manifestado pela não incidência do princípio da igualdade e sua correlata proibição de discriminação nos casos em que se está diante do que denominam "expressive association", associações criadas com a finalidade de defender determinadas posições ideológicas, políticas ou sociais, ou nos casos das "intimate association", caracterizadas pelos profundos vínculos e compromissos de proximidade, privacidade, intimidade entre reduzido número de associados, que se associam com o intuito de compartilharem questões atinentes à sua vida privada. No direito norte-americano tem se considerado que o estabelecimento de critérios de admissão no âmbito das associações privadas pode constituir importante forma de assegurar o exercício da liberdade de expressão pela associação e pelos seus integrantes. ${ }^{21}$

De igual modo, devem ser mencionadas as associações de finalidades religiosas, cuja associação está relacionada a aspectos atinentes ao exercício da liberdade de crença e religião, a qual, também é objeto de proteção constitucional. Nessa hipótese, o estabelecimento de uma obrigatoriedade em se admitir pessoa que não professe a mesma crença religiosa ou professe crença religiosa incompatível com aquela que motiva a existência da associação, representaria a negação ao direito de liberdade de associação e de crença e religião dos demais associados, razão pela qual não se sustenta. ${ }^{22}$ Como impor a uma associação de adventistas que admitam evangélicos, umbandistas, ou pessoas de outras crenças religiosas, sem que haja a frustração da liberdade associativa ou religiosa?

No âmbito da liberdade associativa, a autonomia para estabelecer as condições e requisitos de associação somente deverá ser limitada quando a qualidade de associado for condição direta e inarredável para o acesso aos bens ou serviços

2 I Em caso paradigmático, Boys Scouts of América vs. Dale 530 US 640 (2000), a associação de garotos escoteiros defendeu a licitude de suas regras de associação, as quais excluíam os homossexuais, sob a alegação de que a imposição de sua associação violaria a liberdade de expressão da associação e de seus integrantes, ao obrigar-lhes a consentir e dar uma mensagem de apoio a homossexualidade, o que não desejavam fazer. A Suprema Corte norte-americana acolheu os argumentos apresentados pela associação de escoteiros. Nesse sentido Bilbao Ubillos, 2007, 426. Sobre o caso Boys Scouts of América vs. Dale 530 US 640 (2000), Díaz de Valdés destaca: "Así, por ejemplo, en Estados Unidos se ha considerado que la admisión o selección de miembros puede ser una forma importante de expresión de una asociación y de sus integrantes, la cual se puede ver limitada por normas antidiscriminatorias" (DíAZ DE VALDÉs, 2014, I63).

22 Sobre o conflito entre autonomia privada e liberdade religiosa, Díaz de Valdés suscita: "Otros derechos posiblemente vulnerados por la prohibición de discriminación entre privados son las libertades religiosa y de conciencia. Los problemas aquí han surgido con fuerza en el ámbito de la prestación de servicios y en los colegios, si bien también existen en otras áreas (e.g., acomodación laboral de prácticas religiosas). Gran notoriedad han tenido casos como el rechazo de una pareja de cristianos a alojar parejas bomosexuales en su botel, donde una probibición total de la discriminación entre privados obligaría a quien presta el servicio a actuar en contra de sus convicciones morales y religiosas. En el ámbito escolar han surgido diversos conflictos, varios de ellos centrados en la selección de alumnos y en la posibilidad de los establecimientos educacionales de discriminar en la contratación" (Díaz de VALdÉs, 20 I4, I63). 
essenciais. ${ }^{23}$ Esse seria o caso das associações profissionais cuja condição de associado seja indispensável para o exercício de outros direitos, inclusive para o próprio exercício da liberdade de profissão, o que não impede que estas associações possam estabelecer em seus estatutos sociais e normativas exigências e deveres a serem observados por aqueles que desejam manter a condição de associado, as quais, uma vez descumpridas, poderão justificar a exclusão daquele associado, desde que observado o procedimento estatutário, assegurada a ampla defesa e o contraditório. ${ }^{24}$

\section{B. Igualdade nas relações familiares e sucessórias}

As relações familiares são caracterizadas, notoriamente, por serem permeadas por aspectos relacionados à intimidade, confiança e afetividade entre os indivíduos, de modo que a exigência de tratamento igualitário comprometeria a própria naturalidade ou espontaneidade das condutas humanas. Muitas são as situações que podem aventar discussões acerca da eficácia do princípio da igualdade nas relações jurídicas familiares, todavia, no presente trabalho,a questãoserá analisada a partir de duas distintas e relevantes perspectivas: a igualdade entre cônjuges ou companheiros e a igualdade entre pais e filhos.

O texto constitucional é expresso ao estabelecer a igualdade de homens e mulheres em direitos e deveres, bem como a igualdade no tratamento dos filhos, pouco importando sua origem, se havidos ou não na constância do casamento, de relações extraconjugais ou mediante processo de adoção. A igualdade entre homens e mulheres está relacionada à distribuição equânime dos deveres oriundos da união familiar, distribuição que deverá observar as diferenças naturais existentes entre homens e mulheres, sob pena de, ao se conferir um tratamento rigidamente igualitário, desrespeitar a distinção exigida pelo princípio da igualdade e se desrespeitar as diferenças existentes entre os sexos.

Não se pode olvidar que os papeis e funções exercidas por homens e mulheres nas relações familiares passaram por profundas transformações nas últimas décadas, com a elevação do papel da mulher na família, bem como de sua progressiva inserção no mercado de trabalho, de modo que aquela imagem da família tradicional, formada por marido e mulher, na qual o homem é o responsável pelo sustento financeiro familiar, enquanto a mulher responsável pelos afa-

23 Conforme destaca Bilbao Ubillos: "a limitação da autonomia dos grupos privados só se justifica, do ponto de vista constitucional, quando a pertinência a uma associação incide diretamente na efetiva igualdade de oportunidade dos cidadãos na hora de acessar uma série de bens e serviços, ou desfrutar de certas vantagens econômicas, significativas e demonstráveis" (Bilbao UbiLlos, $2007,428)$

24 Conforme preceitos legais contidos no Art. 57, do Código Civil, "A exclusão do associado só é admissível havendo justa causa, assim reconhecida em procedimento que assegure direito de defesa e de recurso, nos termos previstos no estatuto". 
zeres domésticos e cuidados dos filhos, não é mais a única. Torna-se fenômeno cada vez mais frequente a inversão dos tradicionais papéis familiares, a mulher inserindo-se no mercado de trabalho e o homem assumindo os afazeres domésticos. Além do mais, hodiernamente as famílias são muitas e plurais, fugindo à tradicional formação: famílias anaparentais, monoparentais, formadas em razão de lanços biológicos, afetivos ou sociais.

O princípio da igualdade não possui, em regra, eficácia nas relações familiares entre cônjuges ou companheiros. Desse modo, a eficácia do princípio da igualdade nas relações familiares somente ocorrerá em hipóteses excepcionais, a partir da análise das peculiaridades e especificidades do caso concreto. Inexistindo normas jurídicas de direito privado para adensar o conteúdo do princípio da igualdade para estas relações jurídicas, não poderão os órgãos jurisdicionais, em regra, se imiscuir nas relações íntimas, privadas, cotidianas e domésticas dos cônjuges ou companheiros, para lhe impor uma obrigação de tratamento igualitário, conformando-as. As relações familiares constituem esfera da existência humana em que o princípio da autonomia privada deve prevalecer sobre o princípio da igualdade. ${ }^{25}$ No que tange às relações em que predominam aspectos afetivos, sexuais, íntimos, não há sequer a possibilidade de se cogitar a eficácia do princípio da igualdade. ${ }^{26}$ Destaquese que existem espaços da existência humana que sequer são afetos ao direito. Conforme salienta Steinmetz:

Obrigar os particulares a ter ou a apresentar, sempre, uma justificação racional e objetiva para o tratamento igual ou desigual, seria, na prática, restringir e até mesmo eliminar o direito a fazer escolhas fortuitas, a pautar a sua conduta social por preferências de foro íntimo, a decidir movido por sentimentos de simpatia, empatia e antipatia; em suma, seria restringir ou eliminar o direito de ser livre para conduzir-se segundo motivações não racionalizáveis ou não controláveis intersubjetivamente (Steinmetz, 2004, 262). ${ }^{27}$

25 Conforme destaca Bilbao Ubillos: “a regra geral é a liberdade e, por conseguinte, a inoperância do princípio da igualdade" (Bilbao UbiLlos, 2007, 4I4).

26 Sarmento aduz: "a seara das relações intersubjetivas que se revela mais refratária à incidência direta dos direitos fundamentais não é a dos contratos e negócios jurídicos de conteúdo eminentemente patrimonial, mas das vivências afetivas, quando envolverem opções existenciais e personalíssimas da pessoa humana, que não podem ser heteronomamente ditadas, sob pena de sacrifício do sagrado espaço de autodeterminação individual abrigado sob o pálio da dignidade da pessoa humana. Assim, paradoxalmente, é do princípio da dignidade da pessoa humana fonte axiológica e núcleo irredutível dos direitos fundamentais - que se extrai a mais importante restrição à incidência destes mesmos direitos nas relações entre particulares" (SARMENTO, 2006, 269).

27 Em igual sentido Vieira de Andrade para quem os particulares, por força do princípio da igualdade, não estão obrigados a sempre pautar as suas condutas por imperativos de racionalidade, devendo ser protegidos espaços de agir espontâneos e até mesmo espaços de arbitrariedade na realização de suas escolhas e decisões (VIEIRA DE Andrade, 20 io, 297). Canotilho, em defesa da 
Nas relações entre pais e filhos a eficácia do princípio da igualdade é restrita e cautelosa. O texto constitucional estabelece de forma expressa no parágrafo sexto, de seu artigo 227 , que os filhos, havidos ou não da relação matrimonial, ou por adoção, terão os mesmos direitos e qualificações, sendo proibidas quaisquer designações discriminatórias relativas à filiação. $\mathrm{O}$ referido preceito constitucional materializa o princípio da igualdade e proíbe a prática de discriminações em razão da origem da filiação, não se admitindo qualquer designação que possa sugerir sua origem, o qual é repetido pelo artigo 20 do Estatuto da Criança e do Adolescente. $^{28}$

Ao estabelecer a proibição de discriminação, sobretudo no que diz respeito à qualificação ou designação, o texto constitucional tutela, além do princípio da igualdade, a dignidade dos filhos, evitando que sejam pejorativamente qualificados como adotivos ou espúrios. O tratamento igualitário estabelecido pelo texto constitucional, todavia, não se estenderá às relações afetivas, haja vista que o ordenamento jurídico não pode pretender que os pais manifestem afeto em relação aos filhos com a idêntica intensidade. ${ }^{29}$ Mas então, em que consiste a igualdade de direitos preceituada no parágrafo sexto, do artigo 227 , do texto constitucional?

Seria legítimo aos pais, em razão de sua condição econômica ou objetivando educar seu filho que não demonstra compromisso com os estudos, matriculá-lo em escola pública, como forma de educá-lo, mantendo os demais filhos em escolas particulares? $3^{\circ}$ Seria possível ao pai custear curso de inglês, aulas de natação ou de piano a apenas um dos filhos, e não fazê-lo em relação a um deles? Estariam os pais obrigados a conferir idêntico tratamento aos filhos, lhes assegurando as mesmas condições de acesso a bens e direitos, ou obrigados a lhes conferir idêntico tratamento afetivo?

proteção de um "núcleo irredutível da autonomia pessoal", sustenta que "os direitos fundamentais não podem aspirar a uma força conformadora de relações privadas dado que isso significaria um confisco substancial da autonomia pessoal e à qual não se pode contrapor um direito subjectivo público ou privado, cujo o núcleo essencial seja sacrificado por uma utilização anormal dessa autonomia" (CANotilho, 2006, i I 58 ).

28 Art. 20. Os filhos, havidos ou não da relação do casamento, ou por adoção, terão os mesmos direitos e qualificações, proibidas quaisquer designações discriminatórias relativas à filiação.

29 Segundo preleciona Pinto, "a vida jurídico-privada, para além das incertezas derivadas da caráter muito genérico dos preceitos constitucionais, conheceria uma extrema rigidez, inautenticidade e irrealismo, de todo o ponto indesejáveis" (PINTo, 2007, 75).

30 Conforme entendimento de diversos autores, a diferença de tratamento somente será considerada ilícita quando orientada por um preconceito, tiver por objetivo impor um tratamento injusto, excludente, segregador, ou seja, quando para além da discussão da violação do princípio da igualdade, importar na violação da dignidade do indivíduo que recebeu o tratamento diferenciado. Nesse sentido ver Canotilho (2006, i I 59), Vieira de Andrade (2009, 268), Silva (2008, i68), McCrorie (2005, 47), Bilbao Ubillos (2007, 407-409), Pinto (i999, 77), Águila-Real (i993, i i4) e Steinmetz (2004, 245). 
A própria legislação civil brasileira, assegurando a liberdade contratual e autonomia privada, tutela o tratamento diferenciado no âmbito de relações jurídicas familiares e sucessórias quando, por exemplo, possibilita que o doador ou testador, conforme preceitos legais contidos nos artigos 549 e I 789 ambos do Código Civil ${ }^{\text {I }}$, disponham livremente da metade de seus bens ou da herança. Assim, no que tange à parte disponível, poderá o doador ou testador optar por doá-la ou destiná-la de forma diferenciada entre seus filhos ou, inclusive, doá-la ou destiná-la a apenas um de seus filhos sem que os demais possam nulificá-la sob alegação de violação ao princípio da igualdade. $3^{2}$

Cumpre destacar a possibilidade do pai ou mãe livremente disporem da metade de seus bens ou da herança baseando-se sua decisão na procedência da filiação, por exemplo, ao doar ou testamentar a metade disponível de seus bens exclusivamente aos filhos havidos na constância do casamento ou adotivos, permanecendo a outra metade dos bens sujeitas à partilha legal, não se aplicando,a essas situações, os preceitos constitucionais contidos no parágrafo sexto, do artigo 227 , da Constituição da República, que assegura genericamente a igualdade de direitos entre os filhos. 33 Sobre a questão, Steinmetz se posiciona no sentido de ser permitido à pessoa dispor livremente da fração disponível de seus bens:

Nesse sentido, a título de exemplificação, o testador não está obrigado a dividir em parte iguais os bens que compõem a fração disponível, o comerciante a dar igual desconto no preço de uma mercadoria para amigos e não amigos, o esportista a conceder entrevista a todas as empresas de comunicação, o jornal a publicar na coluna de opinião todos os artigos que recebe, o professor a manifestar simpatia ou amizade por todos os alunos, o médico cirurgião a cobrar igual preço de todos quando igual for o procedimento, o locador a conceder iguais descontos ou carências para todos os seus locatários (Steinmetz, 2004, 262).

O tratamento desigual na distribuição da parte disponível da herança, autorizado pelo ordenamento jurídico, pode ser fruto da desigualdade afetiva, decorrente de uma predileção pura e simples, ou de uma maior preocupação dos

3 I Art. 549: "Nula é também a doação quanto à parte que exceder à de que o doador, no momento da liberalidade, poderia dispor em testamento". Art. I.789: "Havendo herdeiros necessários, o testador só poderá dispor da metade da herança".

32 Neste caso o tratamento diferenciado poderia, inclusive, levar em consideração o fato de se tratar de filho biológico, adotivo ou espúrio. Destaque-se, que no caso específico existe, inclusive, norma constitucional específica relativa a igualdade entre filhos.

33 Poderia se questionar se seria nula uma cláusula testamentária em que um pai preveja a exclusão de uma das filhas da parte disponível da herança caso essa se case com um negro, com homem não católico, ou detentor de outra característica. Nessa hipótese a filha teria o direito de exigir o tratamento igualitário em relação aos demais irmãos? Situação semelhante foi objeto de análise pelo ordenamento jurídico inglês, no caso Blatbwayt v. Baron Cawley, no qual se considerou válida uma cláusula testamentária que continha restrições ao recebimento de herança ao herdeiro que se tornasse católico romano. Em França foi considerada inválida cláusula testamentária que continha restrições ao recebimento de herança caso qualquer dos herdeiros se casasse com um judeu. Clapham (i998, 302) e Raynaud (2003, i I3). 
pais com determinado filho, em razão de eventuais peculiaridades que lhe são inerentes. Não se pode olvidar serem as relações familiares esferas da existência humana em que predomina a autonomia privada, na qual o princípio da igualdade possuirá restrita e excepcional eficácia. Aduzir a eficácia absoluta do princípio da igualdade nas relações paterno-filiais, impondo rigidamente aos pais e filhos que tratem uns aos outros com elegante igualdade em suas relações, obrigandoos a justificar de forma objetiva qualquer desvio dessa regra, produziria consequências absurdas, ${ }^{34}$ decorrentes da jurisdicização de obrigações afetivas.

Quando o texto constitucional preceitua a igualdade entre filhos, não está a impor rigidamente a cada indivíduo que trate os demais com elegante igualdade em suas relações, obrigando-o a justificar de forma objetiva qualquer desvio, mas a proibir que os filhos, em razão de sua origem, recebam tratamentos discriminatórios no que tange a sua qualificação e designação, bem como no sentido de ser proibido que recebam partes desiguais da herança legítima. Não se pode pretender tornar jurídicas obrigações que são essencialmente morais ou afetivas, correndo-se o risco de transformar as relações familiares em manifestações irreais e inautênticas, alicerçadas em falsos ou planejados sentimentos de carinho e amor decorrentes muito mais de uma imposição normativa, do que baseados em sentimentos reais e autênticos de amor, carinho e proteção decorrentes da própria natureza e convivência humanas. ${ }^{35}$

Seria plausível ao ordenamento jurídico exigir dos pais que tratem seus filhos de idêntico modo? Além de ser humanamente impossível exigir o tratamento igualitário, há que se destacar que nem sempre o tratamento igualitário será o desejável, uma vez que este poderia conduzir os filhos a uma situação de iniquidade, pois são, por natureza,diferentes. Um pode ser mais propenso à prática de esportes, outro às artes, outro às línguas estrangeiras, de modo que os pais deverão preocupar-se efetivamente em assegurar aos filhos um ambiente familiar adequado e os meios possíveis para que os filhos possam livremente desenvolver sua personalidade, promovendo sua dignidade. O que o princípio da igualdade e a proibição de discriminação vedam é o tratamento desigual em relação ao dever

Para McCrorie: "A liberdade é liberdade para a irracionalidade, inconsequência, ilógica, incoerência, devendo as relações dos cidadãos entre si ser, em princípio, determinadas pelas próprias partes. É duvidoso que o direito privado, no qual os indivíduos actuam uns com os outros livre e arbitrariamente seja o espaço jurídico para se impor uma moral oficial" (McCrorie, 2005, 45).

35 Sob essa perspectiva é discutível a possibilidade de indenização por abandono afetivo, tal como discutido pelo Superior Tribunal de Justiça, no julgamento do Recurso Especial n. ${ }^{\circ}$ I.I 59.242. Conforme voto preferido pelo Ministro Massami Uyeda: "Ora, se atentarmos para a realidade dos fatos, qualquer filho, qualquer filha, enfim, qualquer pessoa poderá dizer assim: mas estou sendo preterido em relação aos meus irmãos e qualquer dado subjetivo poderia motivar um pedido de indenização por dano moral. Ora, isso faria com que quantificássemos ou potencializássemos as mágoas íntimas - muitas legítimas, algumas supostamente legítimas - de filhos, de irmãos, de pais, de marido e mulher também, porque o dever dos cônjuges está entre prestar assistência, amar e tal. E os estudos indicam que esse amor é uma coisa da convivência" (Superior Tribunal de Justica, Recurso Especial n. ${ }^{\circ}$ I. I 59.242, Rel. Min. Nancy Andrighi; DJ I0.05.20 I 2). 
de amparo, de cuidado, ${ }^{36}$ bem como aqueles tratamentos diferenciados que conduzam o filho a uma situação degradante, vexatória ou humilhante, vulneradora de sua dignidade.

\section{Igualdade nas relações em que predominam aspectos relacionados à intimidade e privacidade, a religiosidade ou confiança}

Nas relações jurídicas entre particulares em que predominam aspectos relacionados à intimidade, privacidade ou confiança o princípio da igualdade terá reduzida ou nenhuma eficácia, especialmente em razão da ausência ou da reduzida repercussão social da conduta. Desse modo, quanto maior for a repercussão social do tratamento diferenciado, maior será a propensão em se admitir a eficácia do princípio da igualdade nas relações jurídicas entre particulares. Deve se verificar se o tratamento diferenciado constituiu uma conduta generalizada e reiterada ou uma conduta praticada no âmbito de um negócio jurídico isolado. 37 Nas relações jurídicas que não possuem ou têm reduzida repercussão social, nas quais predominam aspectos relacionados à intimidade, privacidade e confiança o princípio da igualdade não possuirá qualquer eficácia, sob pena de aniquilamento da autonomia privada supressão do espaço privado de escolhas individuais.

Assim, alguém que deseja organizar sua festa de aniversário ou casamento poderia, por exemplo, demonstrar sua preferência em contratar uma cerimonialista do sexo feminino, por considerá-las mais detalhistas e organizadas, detentoras de características que melhor atendam aos seus interesses. Do mesmo modo, aquele que deseja contratar um motorista para realizar o transporte de uma localidade a outra pode manifestar sua preferência pela contratação de pessoa do sexo masculino ou mais velha, por considerar essas características indicadoras de maior destreza e experiência na condução do veículo automotor. Essa mesma lógica pode ser aplicada para a escolha do empregado doméstico, em razão das especificidades do trabalho a ser realizado, em especial, pelo fato de ser realizado no ambiente familiar.

36 Em igual sentido Azevedo destaca que "o descaso entre pais e filhos é algo que merece punição, é abandono moral grave, que precisa merecer severa atuação do Poder Judiciário, para que se preserve não o amor ou a obrigação de amar, o que seria impossível, mas a responsabilidade ante o descumprimento do dever de cuidar, que causa o trauma moral da rejeição e da indiferença" (Azevedo, 2004, I4).

37 Conforme destaca Bercovitz Rodríguez-Cano: "En principio cabe afirmar que el principio de igualdad tendrá un escaso margen de incidencia en los negocios jurídicos a título gratuito, salvo cuando los mismos [puedan] tener un mayor alcance social [...] Su incidencia será mayor en la contratación dirigida al público en general (prestación que racaiga sobre materias socialmente importantes), sobre todo cuando el sujeto discriminador tenga una posición dominante en el mercado o en la sociedad" (Bercovitz Rodríguez-Cano, I990, 425). 
No âmbito das relações locatícias, poderia o proprietário, ao locar seu imóvel, estabelecer restrição à locação para pessoas que tenham filhos, pessoas jovens, solteiras, proprietárias de cachorro, com o objetivo de assegurar o sossego da vizinhança? No âmbito do contrato de constituição de sociedade empresária, poderia ser estabelecida cláusula proibitiva da transferência das quotas sociais a pessoas do sexo feminino ou possuidora de pouca idade, alegando questões de confiança ou motivações de índole pessoal? Seria lícita a cláusula que, no âmbito de uma convenção de condomínio, estabeleça como exigência para a compra de imóvel que a pessoa comprove possuir determinada renda mínima ou que adote normas específicas para edificação, de modo a assegurar um padrão construtivo para a localidade? Conforme destaca Montoya Melgar:

Do nosso ponto de vista, a proteção da intimidade e da liberdade individual fazem com que cada sujeito, discricionariamente, possa decidir com quem contrata e em que condições e não tem que dar explicações a ninguém, nem justificar suas decisões. O que é preciso combater é a discriminação social, as condutas que tenham uma proteção social e discriminação social, as condutas que tenham uma projeção social e que, em consequência, resultam intoleráveis. É dizer, é preciso combater - se é que existe - a discriminação ao acesso de bens e serviços que se proporcione ao público: seja um simples comércio, a realização de um contrato com uma entidade bancária, etc. Dessa maneira, há que se diferenciar sempre dos níveis: a esfera estritamente privada e os contratos com projeção social ou com consumidores nos quais deve se erradicar qualquer traço de discriminação (Montoya Melgar, 2007, 463, tradução nossa)..$^{38-39}$

Deve-se reconhecer que em relações jurídicas em que há o predomínio de questões atinentes à vida privada ou à esfera familiar é indispensável se resguardar a possibilidade de que os particulares escolham livremente os contratantes que melhor atendam aos seus interesses, tal como ocorre, por exemplo, nas relações jurídicas de natureza associativa ou naquelas referentes à locação de bens

38 Conforme original: "Desde nuestro punto de vista, la protección de la intimidad y de la libertad individual hacen que cada sujeto, discrecionalmente, pueda decidir con quién contrata y en qué condiciones y no tiene por qué dar explicaciones a nadie, ni justificar sus decisiones. Lo que sí se hace preciso combatir es la discriminación social, las conductas que tengan una proyección social y que, en consecuencia, resultan intolerables. Es decir, es preciso combatir -si es que existe-la discriminación en el acceso a bienes y servicios que se proporcionen al público: ya sea un simple comercio, la realización de un contrato con una entidad bancaria, etc. De esta manera, hay que diferenciar siempre dos niveles: la esfera estrictamente privada y los contratos con proyección social o con consumidores, en los que debe erradicarse cualquier atisbo de discriminación".

39 Segundo destaca Aguilera Rull: "Sólo si el trato discriminatorio tiene lugar en el ámbito de la vida privada y familiar, estará éste permitido" (Aguilera Rull, 2009, I6). 
imóveis.40-4I Cerdá Martínez-Pujalte aduz que, "junto com a liberdade de associação, é também relevante a proteção da esfera privada e da vida familiar assim como os negócios existentes neste contexto", e destaca a importância de que, "com referência à vida privada, que inclui a vida familiar, mas vai mais além, se está respeitando o âmbito em que cada pessoa fica livre da observação pública e pode comportar-se assim mesmo, livremente." ${ }^{2}{ }^{-} 43$

Sob essa perspectiva é lícito que aquele que promova a locação de um quarto ou imóvel se recuse a contratar com pessoas do sexo masculino em razão da necessidade de se tutelar a intimidade ou privacidade dos outros locatários do sexo feminino, como ocorre, por exemplo, nas relações locatícias destinadas à constituição de repúblicas estudantis. Nas relações locatícias, os particulares são detentores de uma ampla margem de discricionariedade para estabelecerem as condições e requisitos para a conclusão do negócio jurídico, bem como para elegerem o outro sujeito contratual, desde que o particular não faça uma oferta pública de sua intenção de locar o imóvel, situação na qual estará vinculado às condições previamente estabelecidas.

No que diz respeito às relações privadas em que há influência de aspectos atinentes à religiosidade de um dos contratantes, interessante mencionar e analisar dois casos ocorridos, um na Irlanda do Norte ou outro nos Estados Unidos, que servirão de exemplo para demonstrar quão tormentosa é a questão da eficácia do princípio da igualdade nas relações jurídicas entre particulares. Em ambos os casos, os proprietários de confeitarias se recusaram a fazer, sob encomenda, bolos para casais homoafetivos, alegando que o atendimento ao pedido contrariaria suas convicções pessoais e religiosas.

40 Aqui se refere àquelas relações jurídicas em que um particular aluga seu imóvel, sem que tal ato represente constituía sua atividade empresarial; aqueles casos em que o particular aluga seu próprio imóvel ou parte de seus cômodos a terceiros em uma espécie de pensionato, bem como naquelas em que o imóvel se destina a abrigar público de determinado sexo, tal como ocorre nas repúblicas estudantis.

4I Nesse sentido, de acordo com a Seção I9, da Lei Geral de Tratamento Igualitário alemã: “(3) In the case of rental of housing, a difference of treatment shall not be deemed to be discrimination where they serve to create and maintain stable social structures regarding inhabitants and balanced settlement structures, as well as balanced economic, social and cultural conditions.

"(4) The provisions set out in Part 3 shall not apply to obligations resulting from family law and the law of succession.

"(5) The provisions set out in Part 3 shall not apply to civil-law obligations where the parties or their relatives are closely related or a relationship of trust exists. As regards tenancy, this may in particular be the case where the parties or their relatives use housing situated on the same plot of land. The rental of bousing for not only temporary use shall generally not constitute business within the meaning of Subsection (I) No I where the lessor does not let out more than 4 o apartments in total".

42 Cerdá Martínez-Pujalte, 2009 , 20.

43 De acordo com a exposição de motivos da Diretiva 2004/ I I3/CE, esta reconhece que "ao mesmo tempo que se proíbe a discriminação, é importante respeitar outros direitos e liberdades fundamentais, designadamente a protecção da vida privada e familiar e das transacções efectuadas neste contexto, bem como salvaguardar a liberdade de religião”. 
No caso norte-americano, a Comissão Estadual de Direitos Civis, manifestou-se no sentido de que o confeiteiro estaria obrigado, em nome do princípio igualdade e da proibição da discriminação, a confeitar o bolo, independentemente de sua convicção religiosa. No caso irlandês, a Confeitaria Ashers, nome extraído de uma tribo bíblica de Israel, recusou a confeitar um bolo alegando questões religiosas para justificar a recusa. A justiça de primeira instância considerou a recusa ilícita por ser discriminatória, uma vez que não estaria assentada em qualquer justificativa legítima. 44

\section{Considerações finais}

Uma das temáticas mais controversas e que tem despertado o interesse de inúmeros estudiosos é aquela relativa à eficácia dos direitos fundamentais no âmbito das relações jurídicas entre particulares, em especial, quando o objetivo é definir a extensão da eficácia dos direitos fundamentais nessas relações jurídicas, a qual demanda, necessariamente, a análise das relações existentes entre as normas jurídicas constitucionais e as normas jurídicas de direito privado, bem como o conflito entre direitos fundamentais concretizado no âmbito de relações jurídicas privadas.

O trabalho teve o objetivo de proceder ao estudo da eficácia do princípio da igualdade no âmbito das relações jurídicas entre particulares, com o intuito de contribuir para os debates existentes e aperfeiçoamento das construções teóricas, na tentativa de formular proposições adequadas, capazes de conciliar a tutela do princípio da igualdade e sua correlata proibição de práticas discriminatórias, com a necessidade em se conferir segurança jurídica a estas relações jurídicas, mediante a proteção da autonomia privada e da liberdade contratual, corolários do direito fundamental ao livre desenvolvimento da personalidade.

A questão da eficácia do princípio da igualdade se torna mais conflituosa nas relações jurídicas entre particulares caracterizadas pela simetria das partes, situações em que os particulares se relacionam exercendo livremente sua autonomia privada e liberdade contratual, sem que existam limites estabelecidos pelo legislador. Nestas situações, sustentar a vinculação dos particulares ao princípio da igualdade se apresenta discutível, ao transferir aos órgãos jurisdicionais o poder para intervir na autonomia privada dos sujeitos contratuais e desconsiderar as escolhas por ele realizadas no âmbito da relação jurídica contratual. Essa situação se torna ainda mais questionável quando o negócio jurídico se aperfeiçoou mediante a externalização da vontade de sujeitos plenamente capazes, em uma relação jurídica em que haja considerável simetria.

44 Note-se que em ambos os casos há oferta pública de bens ou serviços, característica que afasta a configuração de ambas situações como relações jurídicas estritamente privadas. 
Inadequado sustentar a eficácia absoluta do princípio da igualdade nas relações jurídica entre particulares, pois esse entendimento comprometeria os espaços privados de decisão e livre atuação do indivíduo, imunes ao direito fundamental à igualdade, que lhes permitem autodeterminar-se conforme suas vontades ou necessidades, corolários para que os indivíduos desenvolvam de forma livre sua personalidade, bem como para a promoção e construção de uma sociedade livre e democrática. Garantir espaços privados de livre decisão e atuação aos indivíduos, nos quais ele poderá atuar sem a necessidade de justificar suas escolhas ou preferências, inclusive ao definir se contratará, com quem e de que forma, não significa transformá-los em espaços institucionalizados para a prática de atos de discriminação baseados em motivos de raça, origem, sexo, etnia ou religião.

Não se deve admitir tratamentos diferenciados desprovidos de qualquer justificativa, tratamentos caprichosos que tenham por objetivo tão somente discriminar a pessoa, de modo a reduzi-la, colocá-la em situação vexatória, degradante ou humilhante. Não devem ser toleradas escolhas ou comportamentos que estejam dissociados do exercício legítimo de direitos fundamentais, em especial, quando baseados na raça, origem étnica ou orientação sexual, os quais, em regra são presumidamente odiosos. O ordenamento jurídico deve rechaçar tratamentos diferenciados que afetem diretamente a dignidade daquele que é discriminado.

Ao se analisar a eficácia do princípio da igualdade âmbito das relações jurídicas entre particulares, indispensável distinguir duas distintas espécies de relações jurídicas: as relações jurídicas estritamente privadas, conformadas entre particulares em situação de relativa igualdade, nas quais a pessoa do contratante é relevante; e as relações jurídicas em que há a oferta e o fornecimento de bens e serviços ao público em geral, caracterizadas como relações de natureza consumerista, nas quais a pessoa do contratante é irrelevante ou pouco relevante, se aperfeiçoando com qualquer indivíduo que aceite as condições propostas pelo ofertante. A distinção se apresenta relevante uma vez que, a depender da natureza jurídica da relação jurídica entre particulares, o grau de eficácia do princípio da igualdade será completamente distinto.

Nas relações jurídicas estritamente privadas, celebradas entre particulares em situação de relativa igualdade, o princípio da igualdade terá reduzida ou nenhuma eficácia. É o que acontece, por exemplo, nas relações jurídicas de locação de bens imóveis, nas relações jurídicas em que a proteção da privacidade, intimidade ou vida privada do contratante é indispensável, naquelas decorrentes do exercício da liberdade associativa, em que o elemento confiança constitui traço característico, nas relações jurídicas familiares e sucessórias, naquelas em que o exercício da autonomia privada está diretamente relacionado às convicções religiosas do contratante, bem como nas relações jurídicas em que a vontade de contratar se dirige a pessoas determinadas. 
Nas relações jurídicas estritamente privadas há que se assegurar ao contratante margem de discricionariedade para exercer sua liberdade de contratação, eleger o outro sujeito contratual, definir a forma e o conteúdo do contrato, de modo a tutelar a autonomia privada do contratante e garantir-lhe a possibilidade de livremente desenvolver sua personalidade de acordo com seus interesses e necessidades. Essas relações jurídicas constituem espaço de liberdade, intimidade e discricionariedade para que os indivíduos possam livremente desenvolver suas relações humanas, sejam afetivas, sexuais, familiares, associativas ou de fraternidade, espaços em que há maior liberdade para que possam adotar decisões de forma autônoma, de modo que, impor-lhes a obrigatoriedade de sempre observar o princípio da igualdade e uma rígida proibição de discriminação, afetaria severa e profundamente a liberdade de decisão e de desenvolvimento dessas relações humanas.

Exigir que particulares, no exercício da autonomia privada e liberdade de contratação, dispensem aos demais particulares idêntico tratamento ou que justifiquem os tratamentos diferenciados realizados configuraria uma restrição demasiada e indevida, representaria impor-lhes um dever positivo de sempre conferir tratamento igualitário aos demais sujeitos privados. Sob a perspectiva da tutela do direito de livremente desenvolver sua personalidade, deve ser assegurado aos indivíduos a possibilidade de construir seus projetos de vida de acordo com seus sentimentos, inclinações pessoais, concepções de mundo. $\mathrm{O}$ exercício da autonomia privada não pode servir de justificativa para legitimar violações à dignidade das pessoas. $\mathrm{O}$ contrato, além de ser corporificador dos interesses individuais dos contratantes, deve ser instrumento para a promoção do livre desenvolvimento da personalidade e da dignidade dos envolvidos.

Será considerado lícito o tratamento diferenciado quando este for indispensável para proteger o núcleo, a essência de outro direito ou bem constitucional, tais como a liberdade de associação, liberdade de crença e religião, intimidade, privacidade e a própria liberdade de contratação, enquanto importantes expressões da autonomia privada. Nestes casos a licitude do tratamento diferenciado decorre da essencialidade desses direitos fundamentais interrelacionados, o que torna mais intensa a necessidade em se proteger a autonomia privada face ao princípio da igualdade e da proibição de discriminação, até mesmo como forma de se assegurar ao particular que possa livremente fazer escolhas, tomar decisões e desenvolver aspectos existências de seu projeto de vida. Nos casos em que a autonomia privada estiver alicerçada apenas ou preponderantemente em aspectos de natureza patrimonial ou econômica, a proteção da autonomia privada se dará de forma menos intensa face ao princípio da igualdade e à correspondente proibição de discriminação.

A eficácia do princípio da igualdade e da correlata proibição de discriminação face à autonomia privada dependerá, portanto, das especificidades da relação jurídica privada, dos direitos fundamentais em conflito, dos bens constitucionais 
cujo tratamento diferenciado se restringiu, se existenciais ou patrimoniais, das circunstâncias fáticas e jurídicas, do grau de simetria entre as partes, da autenticidade da vontade externada pelos contratantes, da transcendência ou repercussão social da diferenciação, e da análise da possível afetação da dignidade da pessoa discriminada, critérios a serem utilizados com o objetivo balizar e estabelecer diretrizes interpretativas de modo a reduzir o subjetivismo das decisões jurisdicionais, evitando o esvaziamento do conteúdo da autonomia privada em razão de um intervencionismo jurisdicional nas relações jurídicas contratuais entre particulares.

\section{Referências bibliográficas}

Aguilera Rull, Ariadna. "Prohibición de discriminación y libertad de contratación”, Revista para el Análisis del Derecho, Faculdad de Derecho de la Universidad Pompeu Fabra, 2009, I-30.

Aguilera Rull, Ariadna. "El proyecto de ley integral para la igualdad de trato y la no discriminación”, Revista para el Análisis del Derecho, Faculdad de Derecho de la Universidad Pompeu Fabra, 20 I I, I-I 5.

Aguilera Rull, Ariadna. Contratación y diferencia: probibiciones de discriminación por sexo y origen étnico en el acceso a bienes y servicios disponibles al público, Universitat Pompeu Fabra, 20 Io.

Alfaro Águila-Real, Jesús. "Autonomía privada y derechos fundamentales", Anuario de Derecho Civil, I993, 57-I 22.

Bilbao Ubillos, Juan María. Los derechos fundamentales en la frontera entre lo público y lo privado: la noción de state action en la jurisprudencia norteamericana, Madrid, McGraw-Hill, I997.

Bilbao Ubillos, Juan María. La eficacia de los derechos fundamentales frente a particulares, Madrid, Centro de Estudios Políticos y Constitucionales, I997.

Bilbao Ubillos, Juan María. "La eficacia frente a terceros de los derechos fundamentales en el ordenamiento español”, en Pinto Monteiro, Antonio; Neuner, Jorg y Sarltet, Ingo Wolfgang (orgs.). Direitos fundamentais e direito privado: uma perspectiva de direito comparado. Coimbra, Almedina, 2007, I 45 -I 63.

Bilbao Ubillos, Juan María. ¿En qué medida vinculan a los particulares los derechos fundamentales?, en SARLET, INGo (org.). Constituição, direitos fun- 
damentais e direito privado, 2." ed., Porto Alegre, Livraria do Advogado, 2006, 3OI-340.

Bercovitz Rodríguez Cano, Rodrigo. Principio de igualdad y derecho privado. Anuario de Derecho Civil, I990, 369-427.

Canotilho, Joaquim José Gomes. Dogmática de direitos fundamentais e direito privado, en Canotilho, JoAquim José Gomes. Estudos sobre direitos fundamentais, Coimbra, Coimbra Editora, 2004, I90-2 I 5 .

Carrasco Perera, Ángel. El principio de no discriminación por razón de sexo, Revista Furídica de Castilla-La Mancha, I990, 9-38.

Caupers, João. Os direitos fundamentais dos trabalhadores e a Constituição, Lisboa, Almedina, I985.

Cerdá Martínez-Pujalte, Carmen. "El problema de la discriminación en el ámbito privado: una aproximación a las legislaciones recientes en Alemania y España”, Revista de Derecho Privado, Universidad Externado de Colombia, n. ${ }^{\circ}$ I6, 2009 , го3-г46.

Chemerinsky, Erwin. "Rethinking State Action", Northwestern University Law Review, vol. 8o, n. ${ }^{\circ}$, I985, 503-557.

Cifuentes Muñoz, Eduardo. "La eficacia de los derechos fundamentales frente a particulares”, Cuadernos Constitucionales México-Centroamércia, n. ${ }^{\circ} 27$, Universidad Nacional Autónoma de México, Corte Constitucionalidad de Guatemala, I 998.

Clapham, Andrew. Human rigths in the private sphere, Oxford, Claredon Press, I998.

Cruz Villalón, Pedro. Derechos fundamentales y derecho privado, Madrid, Academia Sevillana del Notariado, Edersa, i 998.

Díaz De Valdés, José Manuel. "La prohibición de una discriminación arbitraria entre privados", Revista de Derecho de la Pontificia Universidad Católica de Valparaíso, XLII, primer semestre de 20I4, I49-I 86.

Díez-Picazo, Luis María. Sistema de derechos fundamentales, Madrid, Thomson/ Civitas, 2007. 
Gálvez Muñoz, Luis. "La cláusula general de igualdad", Anales de Derecho, n. ${ }^{\circ}$ 2 I, Universidad de Murcia, 2003, I95-206.

Fernández Crende, Antonio. "Seguros de vida y discriminación sexual”, Revista para el Análisis del Derecho, n. ${ }^{\circ}$ 4, Barcelona, 2004, I-26.

Jiménez Campo, Javier. Derechos fundamentales: concepto y garantias. Madrid, Trotta, I999.

Julio Estrada, Alexei. La eficacia de los derechos fundamentales entre particulares. Bogotá, Universidad Externado de Colombia, 2000.

Leisner, Walter. Grundrechte und privatrecht. Múnich, I96o.

Ludwig, Marcos De Campos. "O direito ao livre desenvolvimento da personalidade na Alemanha e possibilidades de sua aplicação no direito privado brasileiro", en Martins-Costa, Judith (org.), A reconstrução do direito privado. São Paulo, RT, 2002.

Martínez Vázquez de Castro, Luis. El principio de libre desarrollo de la personalidad en el ámbito privado. Pamplona, Civitas, 20 Iо.

Martins, Leonardo. "Livre desenvolvimento da personalidade", en Schwabe, Jürgen. Cinqüenta años de jurisprudência do Tribunal Constitucional Federal alemão. Berlin: Konrad Adenauer-Stiftung, 2005.

Mc Crorie, Benedita Ferreira da Silva. A vinculação dos particulares aos direitos fundamentais. Coimbra: Almedina, 2005.

Montoya Melgar, Alfredo y Sánchez-Urán Azaña, Yolanda (coords.), Igualdad de mujeres y hombres. Comentario a la Ley orgánica 3/20o7, de 22 de marzo, para la igualdad efectiva de mujeres y hombres, Cizur Menor, Thomson Civitas, 2007 .

Naranjo de la Cruz, Rafael. Los límites de los derechos fundamentales en las relaciones entre particulares: la buena fe. Madrid, Centro de Estudios Políticos y Constitucionales, 2000.

Neuner, Jorg. "A influência dos direitos fundamentais no direito privado alemão”, en Monteiro, António Pinto; Neuner, Jorg; Sarltet e Ingo WolFGANG (orgs.). Direitos fundamentais e direito privado: uma perspectiva de direito comparado. Coimbra: Almedina, 2007, 2 I 3-236. 
Novais, Jorge Reis. Os direitos fundamentais nas relações jurídicas entre particulares, in Sarmento, Daniel Antônio de Moraes (org.). A constitucionalização do direito. Rio de Janeiro, Lúmen Iuris, 2007.

Nowak, John E. e Rotunda, Ronald D. American Constitucional Law. 5. ${ }^{\mathrm{a}} \mathrm{ed}$. Saint Paul, West Plublishing, I995.

Peces-Barba Martínez, Gregorio. Curso de derechos fundamentales. Madrid, Universidad Carlos iı de Madrid e Boletín Oficial del Estado, I999.

Pérez Luño, Antonio Enrique. Los derechos fundamentales. 9. ${ }^{a}$ ed. Madrid, Tecnos, 2007.

Picker, Eduard. Anti-discrimination as a Program of Private Law? German Law Journal, Russel A. Miller (ed.), vol. 4, n. ${ }^{\circ}$ 8, 2003.

Pinto, Paulo Mota. A influência dos direitos fundamentais sobre o direito privado português, in: Monteiro, António Pinto; Neuner, Jorg e Sarltet, Ingo Wolfgang. (orgs.). Direitos fundamentais e direito privado: uma perspectiva de direito comparado. Coimbra, Almedina, 2007, I45-163.

Prieto Sanchis, Luis. Estudios sobre derechos fundamentales. Madrid, Debate, I994.

Queiroz, Cristina M. Direitos fundamentais: teoria geral. Coimbra, Coimbra Editora, 2010.

SARAzá Jimena, Rafael. Fueces, derechos fundamentales y relaciones entre particulares, Logroño, Universidad de La Rioja, 2008.

Sarlet, Ingo Wolfgang. A eficácia dos direitos fundamentais, 8. ${ }^{a}$ ed. Porto Alegre, Livraria do Advogado, 2007.

Sarmento, Daniel Antonio de Moraes. Direitos fundamentais e relações privadas. 2. ${ }^{\mathrm{a}}$ ed. Rio de Janeiro, Renovar, 2008.

Steinmetz, Wilson. A vinculação dos particulares a direitos fundamentais. São Paulo, Malheiros, 2004 .

Silva, Virgílio Afonso da. A constitucionalização do direito: os direitos fundamentais nas relações entre particulares. São Paulo, Mandamentos, 2008. 
Silva, Virgílio Afonso da. Direitos fundamentais: conteúdo essencial, restrições e eficácia. São Paulo, Malheiros, 2009.

Vasconcelos, Pedro Pais de. Direito da personalidade. Coimbra, Almedina, 2006.

Vargas Vasserot, Carlos. "El sexo como factor de riesgo en los seguros". in Pérez Vallejo, Ana María (coord.) Igualdad efectiva entre mujeres y hombres: diagnóstico y prospectiva. Barcelona, Atelier Libros, 2009.

Venegas Grau, María. Derechos fundamentales y derecho privado: los derechos fundamentales en las relaciones entre particulares y el principio de autonomia privada, Madrid, Marcial Pons, 2004.

Verda y Beamonte, José Ramon. "Eficácia privada de los derechos fundamentales y recurso de amparo", Revista Boliviana de Derecho, n. ${ }^{\circ}$ I , enero, 20 2 , 40-59.

Viera de Andrade, José Carlos. Os direitos fundamentais na Constituição portuguesa de $1976.3 .^{\text {a }}$ ed. Coimbra, Almedina, 2009. 